\title{
Review
}

\section{Sublethal Damage to Erythrocytes during Blood Flow}

\author{
Mesude Avc1 ${ }^{1}$, Edgar A. O’ Rear ${ }^{2,3, *(D)}$, Kylie M. Foster ${ }^{2}$ (D) and Dimitrios V. Papavassiliou ${ }^{2}(\mathbb{D}$ \\ 1 Department of Chemical Engineering, Cumhuriyet University, Sivas 58140, Turkey; \\ mesude@cumhuriyet.edu.tr \\ 2 Department of Chemical, Biological and Materials Engineering, University of Oklahoma, \\ Norman, OK 73019, USA; kylie.m.foster-1@ou.edu (K.M.F.); dvpapava@ou.edu (D.V.P.) \\ 3 Institute for Biomedical Engineering, Science and Technology, Norman, OK 73019, USA \\ * Correspondence: eorear@ou.edu; Tel.: +1-(405)325-4379
}

check for updates

Citation: Avc1, M.; O’Rear, E.A.; Foster, K.M.; Papavassiliou, D.V. Sublethal Damage to Erythrocytes during Blood Flow. Fluids 2022, 7, 66. https://doi.org/10.3390/

fluids7020066

Academic Editors: Laura A. Miller and Arvind Santhanakrishnan

Received: 29 November 2021

Accepted: 26 January 2022

Published: 7 February 2022

Publisher's Note: MDPI stays neutral with regard to jurisdictional claims in published maps and institutional affiliations.

Copyright: (c) 2022 by the authors. Licensee MDPI, Basel, Switzerland. This article is an open access article distributed under the terms and conditions of the Creative Commons Attribution (CC BY) license (https:// creativecommons.org/licenses/by/ $4.0 /)$.

\begin{abstract}
Mechanical circulatory support (MCS) devices are designed to perform the functional needs of organs and to meet clinical hemocompability criteria. Critical complications have been reported with their long-term use such as thrombosis, anemia and gastrointestinal bleeding. Damage to red blood cells (RBCs), which occurs with nonphysiological blood flow conditions such as contact with foreign surfaces, high shear stress, and turbulence, is a major problem for the design and development of these systems. Even in the absence of hemolysis, cardiovascular devices (CAD) still cause cell injury and shortened RBC lifespans. This review summarizes various effects that occur to erythrocytes exposed to supraphysiological but sublethal stresses.
\end{abstract}

Keywords: heart assist devices; erythrocyte; erythrocyte deformability; hemolysis; RBC mechanical fragility; sublethal damage; mechanical trauma

\section{Introduction}

Blood constitutes about $8 \%$ of an average adult's body weight and its role is to transport material to and from tissue, prevent fluid loss, and defend the body. Blood is a mixture of plasma, which makes up 55\% of blood's volume, and blood cells, which make up the remaining $45 \%$. While plasma consists of water, proteins, inorganic salts, and organic substances, blood cells include white blood cells (leukocytes, WBCs), platelets, and red blood cells (erythrocytes, RBCs). The most abundant cells in vertebrate blood are RBCs. A human RBC is a nucleus-free cell with a lipid bilayer membrane over a protein cytoskeleton encapsulating a hemoglobin solution (Figure 1). Because of the fluidic nature of hemoglobin and the elastic nature of the RBC membrane, the RBC is capable of dramatic deformations and it exhibits rich dynamics, while the membrane surface area and volume remain constant [1-3].

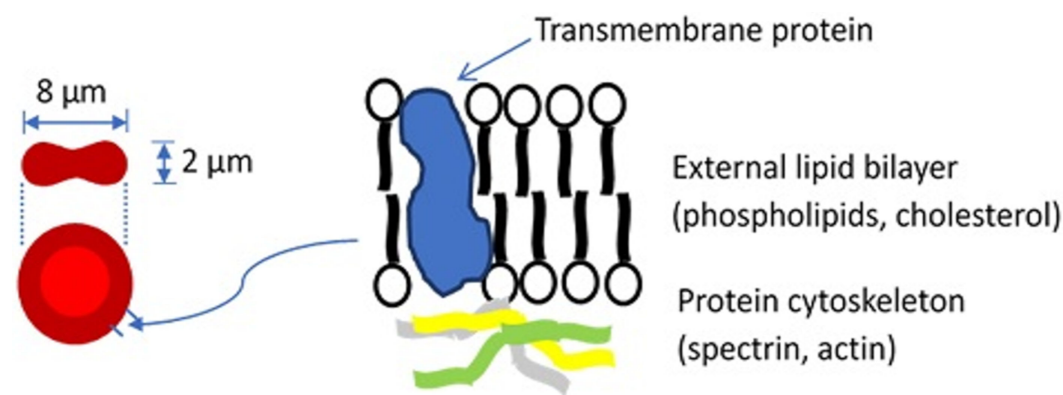

Figure 1. Basic structure of the red blood cell. For a more detailed description of the cell membrane structure, the reader is referred to a review by Discher and Carl [4].

Injury to blood cells by fluid forces was recognized with the development of artificial organs in the 20th century. Mechanical circulatory support devices were designed to per- 
form the functional needs of the replaced organs while meeting clinical hemocompatibility criteria [5-7]. Critical complications emerged with long term use, such as damage to blood tissues. Early research focus was on RBCs that experienced injury, apparent in abnormal cell morphology and release of hemoglobin from the cells, hemolysis. It was found that mechanical forces would cause cells to rupture or possibly lose hemoglobin through pores while remaining intact [8].

Damage to RBCs, which results from nonphysiological flow (e.g., high shear stress, turbulence, cavitation, etc.), is a major problem for the design and development of extracorporeal pumps and other medical devices [1-4]. Figure 2 shows that hemolysis varies with the magnitude of the shear stress and its duration.



Figure 2. Hemolysis threshold as a function of stress magnitude and duration. Cell damage has been shown by other measures in the subhemolytic regime (after Leverett et al. [9]).

At a sufficiently long exposure, or sufficiently high level of stress, hemolysis occurs. Cells may experience short-term, intermittent periods of stress in MCS. It has been shown that the exposure resulting in injury need not be continuous. Horobin observed hemolysis after 60 cycles of $100 \mathrm{~Pa}, 1 \mathrm{~s}$ duration stress every $60 \mathrm{~s}$ [10]. Establishing the conditions for hemolysis helped engineers to improve designs of cardiovascular devices (CADs) and reduce the harm to cells. As a result, instances of clinical hemolysis have continued to decline [11]. Even if risk of hemolysis is lower, CADs still cause cell injury [11-13]. Therefore, investigation of hemolysis, anemia, or thrombosis in CAD patients requires paying attention to the biochemical and rheological impact of sublethal damage to blood [14].

Very early Galletti realized that, other than hemolysis, more subtle forms of injury were possible. Even though cells displayed normal morphology, injury was evident from increased mechanical fragility during animal experiments with extracorporeal circulation [15-17]. This led to the idea of sublethal trauma, introduced by Brinsfield et al. [16]. Others, including Kusserow et al. [18] and Bernstain et al. [19,20], noticed anemia and decreased cell survival rates in animal tests. Sandza et al. [21] demonstrated a connection to mechanical forces when they perfused an isolated rabbit spleen with a mixture of sheared and unsheared RBCs; sheared cells were selectively separated by the spleen. This showed that subhemolytic trauma causes accelerated removal of RBCs from circulation.

The effects of fluid forces became more widely appreciated as clinical use of cardiopulmonary bypass machines and hemodialysis units increased. Stress affected red cells as well as other blood components (including platelets, white blood cells, von Willebrand factor) [14]. With time, the emphasis on hemolysis for RBC damage has decreased while other forms of injury to red cells became more relevant. Subhemolytic injury, defined by Sutera [22] as trauma with leakage of intracellular hemoglobin through membrane pores without cell rupture, occurs when the RBC membrane is continually stressed under nonphysiological conditions below the threshold for hemolysis. Compared to hemolysis, 
sublethal trauma is more complex to identify and characterize [14], though the effects of sub-hemolytic damage are evident in patients with assistive devices [13,17]. Consequently, the susceptibility of blood to sublethal trauma has become an important area of study.

Characterizing the conditions resulting in cell injury and the development of equations to predict damage [23] with computational fluid dynamics simulations has helped to improve the design of medical devices with reduced hemolysis. However, there is limited corresponding research to predict sublethal injury to blood in laminar or turbulent flows. In an interesting comparison of laminar and turbulent flow [24], it was found that, at the same wall shear stress in a capillary tube, the level of hemolysis was significantly greater for turbulent flow than in laminar flow. This confirmed that turbulent stresses contribute strongly to blood mechanical trauma. More work is needed to determine the nature of cell injury and turbulent flow conditions that harm the red cells. James et al. [25] predicted the RBC trauma from turbulence, including hemolysis, with a three-dimensional model of a bileaflet artificial heart valve using a recently developed empirical model $[26,27]$. In their work, analysis of the size of turbulent eddies relative to the size of the RBCs was used to suggest that the smallest turbulence eddies can be used to model sublethal trauma in turbulent flow. Very little experimental research in this area has been carried out in well-defined systems with turbulent flows. Aziz et al. [28] evaluated sublethal damage to porcine red cells caused by turbulence and characterized injury using osmotic fragility testing. During osmotic fragility testing, Aziz et al. [23] plotted \%lysis versus salt osmolarity $(\mathrm{g} \mathrm{NaCl} / \mathrm{L})$ and they found that a statistically significant right shift occurred in the population exposed to turbulence, a confirmation of sublethal cell damage.

We review in this article the various effects that occur to erythrocytes exposed to supraphysiological but sublethal stresses.

\section{Factors That Affect RBC Sublethal Trauma}

\subsection{Effect of Shear Stress and Shear Rate}

Although the highest value of shear stress in the human circulatory system reaches up to $15 \mathrm{~Pa}$ [29], MCS devices (e.g., artificial blood pumps) briefly expose RBCs to much higher levels, even up to $1000 \mathrm{~Pa}$ or more [30]. As a result of such supraphysiological shear stresses, the mechanical properties of RBCs may be altered and RBC deformability affected [31-34]. High speed rotors inside MCS devices create non-physiological shear stress (NPSS) during clinical applications [35]. It was found that maximum scalar shear stress can reach as high as $3000 \mathrm{~Pa}$ on blade tip regions of the impellers of the devices [36]. Exposure to short-term and repeated shear stress in circulation also leads to accumulated sublethal damage [10]. Simmonds defined mechanical sensitivity in order to characterize RBC susceptibility to shear stress [37]. This measure was used to map out tolerance of the red blood cell to shear stress in relation to deformability for exposure times ranging from $0-16 \mathrm{~s}$ and shear stresses of $0-100 \mathrm{~Pa}$ [38]. A plot depicting different regimes similar to the domains found for the thresholds for hemolysis (Figure 3) was produced.

Higher shear rates and stresses affect the cell in a variety of ways, such as its tendency to adhere to the vessel wall, a property shared with sickle cells [39]. By simulating injury to cells in the lab with well-defined flow fields, researchers have determined many effects due to mechanical trauma. RBCs from healthy donors exposed to shear in a Couette device exhibited an increasing elastic shear modulus (39 to 69\%) on increasing shear stress from $50 \mathrm{~Pa}$ to $100 \mathrm{~Pa}$ [40]. However, cell transit velocity did not change with shear under these conditions. Buerck et al. [11] studied sub-hemolytic damage to erythrocytes in microfluidic channels at high shear rates similar to those in ventricular assist devices. In this work, increased RBC microparticle concentrations were used to indicate the level of sub-hemolytic damage. McNamee et al. [41] investigated aggregation behavior and biochemical properties of RBCs. They found that high shear stress resulted in many changes to the cell. Exposure to shear has the following effects: (i) increases magnitude and rate of RBC aggregation; (ii) increases tendency of RBCs to aggregate in a standardized plasmafree medium (i.e., aggregability); (iii) increases amount of shear required to disaggregate 
formed rouleaux; (iv) splits membrane-bound sialic acid into the surrounding media; and, (v) reduces electrostatic charge of RBCs (observed via decreased electrophoretic mobility), and thus also the cells' zeta potential [41]. Sakota et al. [42] measured mean cell volume $(\mathrm{MCV})$, mean cell hemoglobin concentration $(\mathrm{MCHC})$, mean cell hemoglobin $(\mathrm{MCH})$, and plasma-free hemoglobin for whole blood circulated for $6 \mathrm{~h}$ in a series of different rotary blood pumps as well as a roller pump. They concluded that a decrease in $\mathrm{MCH}$ was a result of subhemolytic damage, since the concept of subhemolytic RBC trauma has been introduced by Sutera [22] as intracellular hemoglobin leaks through membrane pores without cell rupture.

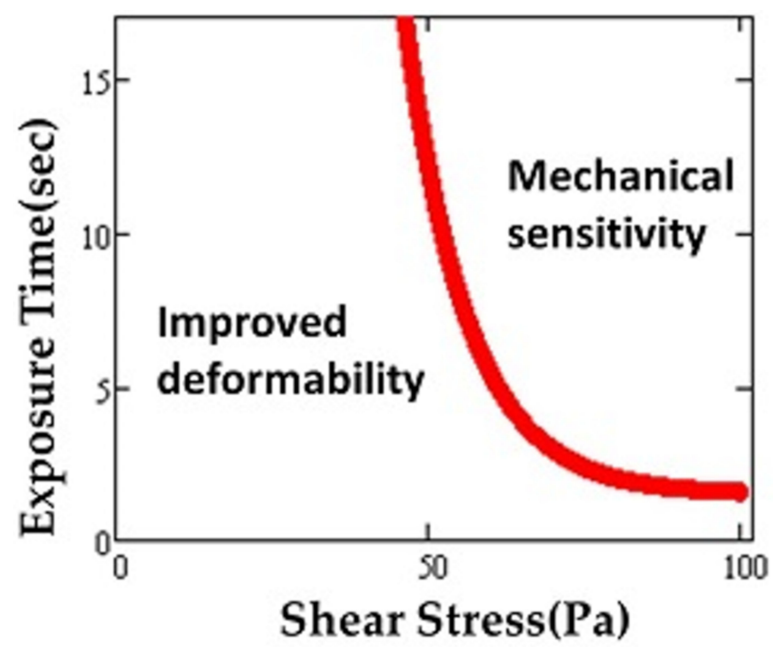

Figure 3. Region of sublethal trauma determined by "mechanical sensitivity". Possible improvement in deformability occurs under some conditions. Adapted from reference [38].

\subsection{Effect of Elongational Stress}

Throughout the history of CAD design, shear stresses have been the predominant focus when limiting damage to blood components. While these devices do have supraphysiologic levels of shear stress, elongational (or extensional) stresses are also present in these devices [43], particularly where contractions/expansions in flow occur. While shear stresses impart friction-like forces on RBCs, causing the cells to elongate and exhibit an antisymmetric "tank treading" motion [44], elongational flow results in symmetric stretching with no such membrane motion. Many studies have examined the effects of shear stress on RBCs as mentioned above, but there are few and far between that have examined the effect of elongational stresses on RBCs. Faghih and Sharp reported that RBCs deform to a greater extent under elongational flow than under shear flow, and that the magnitude of elongational stress was 34 times smaller than the shear stress required to reach the same deformation [45]. Lee et al. observed similar results [46]. Neither study observed any hemolysis, nor did they attempt to examine any possible markers of sublethal damage. The enhanced deformation under elongational stresses would suggest that this type of flow might be more damaging both in terms of hemolysis and sublethal damage [47].

While no work to our knowledge describes sublethal damage to RBCs under elongational flow, there are several studies that examine other blood components. Purvis et al. showed that elongational stress induces platelet aggregation as well as impairs the platelet's response to ADP [48]. Leukocyte suspensions in contraction expansion array microchannels (dominated by shear and elongational stresses), used for inertial cell separation, showed increased intracellular damage over spiral microchannel designs (dominated only by shear stress) [49]. This suggests that the elongational stresses are the main contributing factor to the observed intracellular damage. Von Willebrand factor (vWf), a common protein involved in hemostasis, is also susceptible to elongational stresses. Unraveling of vWf from its globular form has been observed under elongational flows [50,51]. The unfolding of vWf can lead to flow-induced thrombus formation by exposing activation sites, as well 
as result in bleeding complications caused by the degradation of vWf from the exposed cleavage sites. Other cell types have been studied as well, mostly in application to potential damage from bioreactor environments or scaffolding manufacturing. Bae et al. studied Chinese hamster ovary $(\mathrm{CHO})$ cells exposed to elongational stresses and established a threshold of $\sim 250 \mathrm{~Pa}$ after which damage to $\mathrm{CHO}$ cells occurred, marked by a decrease in cell viability [52]. Elongational stresses experienced in extrusion-based bio printing have also been shown to be a more significant factor than the present shear stresses when it comes to cellular damage [53]. Cellular damage being defined as membrane failure, cellular dysfunction, and decreased viability. Elongational stress clearly plays a significant role in damage to different cell types and blood components. The lack of work regarding sublethal damage and hemolysis to RBCs under elongational flow presents a pathway for future work that would be valuable in furthering understanding of the effects of CADs and informing their future design.

\subsection{Effect of Mechanical Fatigue}

Effects of mechanical fatigue on biological cell deterioration are not well understood. RBCs deform regularly when they are traversing microvasculature and the harmful effects of physiological fatigue on properties and homeostasis of RBCs remain unclear [54]. When the fatigue effect on RBCs is compared to static deformation under the same maximum load and maximum load duration, a deterioration of mechanical properties is found. Some medical devices contribute to additional nonphysiological fatigue damage and hemolysis [55]. Recently, Qiang et al. [54] studied mechanical fatigue effects on single red cells by using an electrodeformation method. Shear modulus and shear viscosity after 900 approximately $1 \mathrm{~s}$ deformation cycles were much higher than the highest value for a healthy cell. After approximately 400 cycles, permanent deformation was observed.

\section{Sublethal Trauma Leading to RBC Deformability Changes}

Many would consider altered blood rheology the most significant effect of sublethal trauma. It can cause the cells to become less flexible, undermining their normal functioning in the delivery of oxygen throughout the body. Some of the extreme effects of stiff red cells are widely known from sickle cell anemia and other diseases. Sickle cell anemia patients suffer painful crises due to the rigid erythrocytes blocking narrow capillaries and starving tissues of oxygen. Moreover, the inability of a red cell to traverse slits between the endothelial cells lining the venous sinuses of the spleen leads to its removal from circulation [56] and an abridged lifespan of the cell (Figure 4 [57]). In another condition, hereditary spherocytosis, the spleen becomes enlarged as it filters out the rigid red cells generated in this disease. Treatment often involves removal of the spleen. These pathologies help to illustrate the implications of the compromised erythrocyte deformability associated with sublethal trauma.

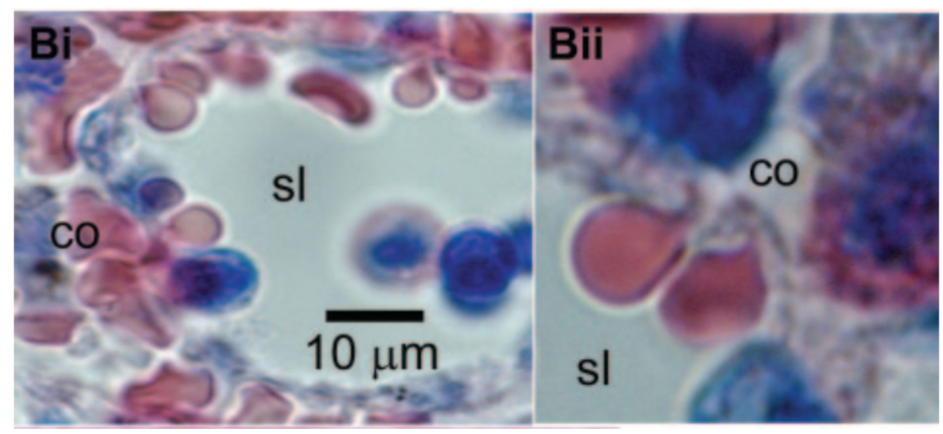

Figure 4. Red blood cells must squeeze through intercellular clefts of endothelial cells between the red pulp and venous sinuses of the spleen in order to return to the circulation. Cells in these images illustrate the degree of deformation required to pass through the spleen. Sublethal trauma compromises the ability of the red cell to survive this challenge. Reprinted with permission from Ref. [57]. Copyright 2006 Elsevier . 


\subsection{Indication of Sublethal Trauma from Measurement of Erythrocyte Deformability}

Change to red cell rheology represents a common method to detect the possibility of mechanical trauma. Many methods have been developed to assess the rheological properties of red cells under flow for the better understanding of cardiovascular physiology and pathologies [58]. Each technique offers different sensitivity to the main factors determining deformability: (a) surface-to-volume ratio; (b) internal viscosity; and (c) membrane viscoelastic properties. Knowledge of these factors can help to point to underlying mechanisms related to cell injury.

The most commonly used methods have been the ektacytometer (Figure 5) and filtration [59-61]. The ektacytometer employs a concentric cylinder geometry similar to a Couette cup-and-bob viscometer to deform the cell. When observed in a laminar flow field of the instrument, the red blood cell exhibits an ellipsoidal shape. Deformability is characterized by the aspect ratio $(\mathrm{L} / \mathrm{W})$ or more commonly by the deformation index, DI, also called the elongation index, EI, defined as $\mathrm{EI}=(\mathrm{L}-\mathrm{W}) /(\mathrm{L}+\mathrm{W})$ where $\mathrm{L}$ is the length of the RBC major axis and $\mathrm{W}$ is the length of its minor axis. Light diffraction measurements yield the values of the EI in the ektacytometer and a scan as a function of shear rate can yield other parameters that characterize cell rigidity, such as the maximum EI, EImax.

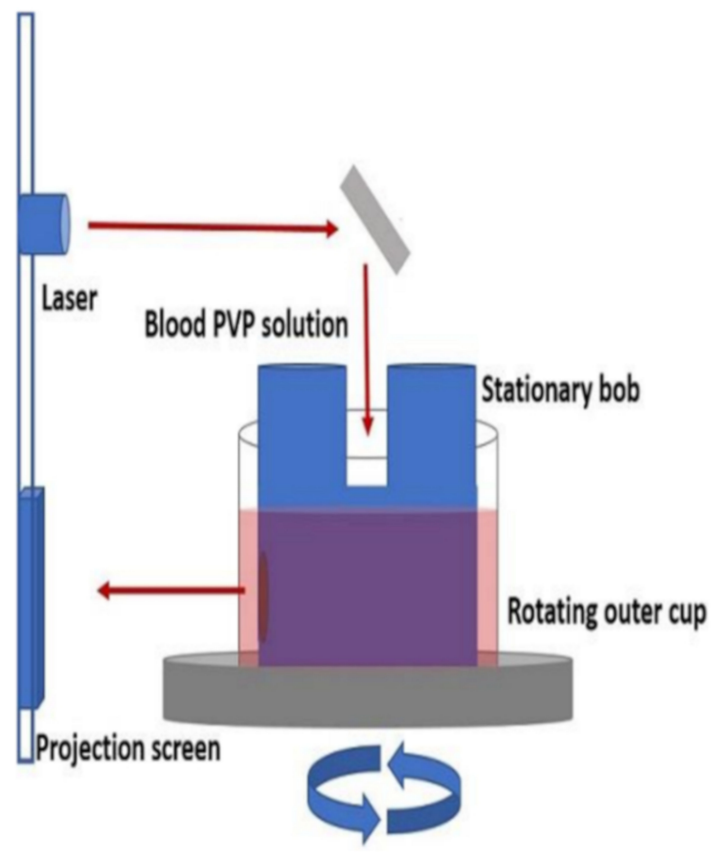

Figure 5. Schematic of ektacytometer setup. Reprinted with permission from Ref. [62]. Copyright 2018 JoVE.

Another way to determine the rheological behavior of the RBCs is the "filterability test" [34], with cells traversing a porous membrane. Teitel and Rădulescu assessed "plasticity" of red blood cells by passage through filter paper as early as 1952 [63]. Many variations have been developed since to measure "filterability" with later methods using polycarbonate membranes or metal discs with pores of known size and uniform diameter, typically $3-5 \mu \mathrm{m}$. Two fundamental cases can be described, using constant pressure or constant flowrate (Figure 6).

These correspond roughly to classical constant stress and constant deformation rate material tests. Several labs have sought to develop systems for commercialization with variations from the fundamental cases above. For example, some investigators simply use gravity for filtration and compare the volume passing through the filter within a specified time interval. The size and structure of the pores of a membrane can be important features of the instrument. Groups in Japan used microlithography to create pores with a uniform size and grid spacing on a metal membrane [64]. Polymeric membranes formed 
by track etching to create pores have also been popular [65]. More recently, flow through constrictions of various geometries in microfluidic channels has enabled a determination of cell rheology with small sample sizes $[58,66]$.
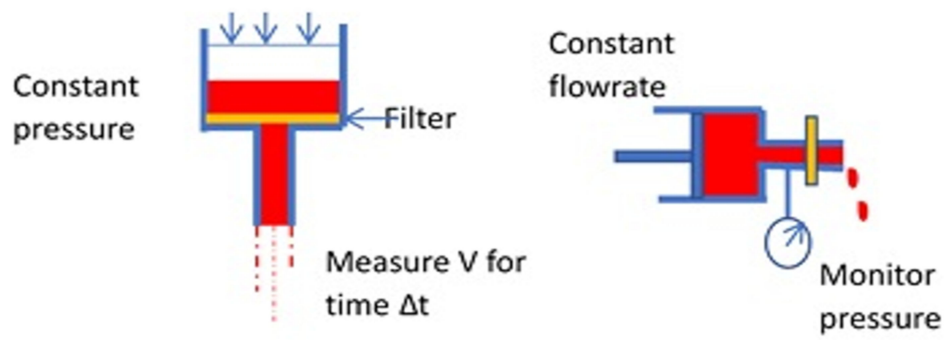

Figure 6. Basic modes of the filtration test for erythrocyte deformability.

Other techniques include optical tweezers and micropipette aspiration. In contrast to the measurement of cell rheology in the shear flow field of the ektacytometer, recent work indicates that cells deform to a greater extent in an elongational flow field than they do in a shear field of the same stress level [45]. Researchers in this area have typically used microfluidics with a converging bilaterally symmetric hyperbolic channel or a crossflow channel reminiscent of Taylor's 4-roll mill [47]. In these systems, DI is found from images of cells moving along the centerline. As a practical application, assessment of DI by extensional stresses has been adapted for high throughput phenotyping of cells [67].

\subsection{Altered Deformability by Mechanical Trauma in Medical Devices}

Blood experiences supraphysiologic levels of shear with mechanical circulatory support including total artificial hearts, ventricular assist devices, and ECMO (extracorporeal membrane oxygenation) units. Left ventricular assist devices (LVADs) are used as a bridge to transplant for patients with end-stage heart failure. With limited availability of donor hearts, LVADs also function as a destination therapy to extend the life of an individual. These devices, which could help as many as 250,000 patients [68], have improved greatly and yet still impose supraphysiologic stresses on blood. By monitoring pressure during constant flow rate filtration of an RBC suspension through $3 \mu \mathrm{m}$ pores of a membrane, Hung et al. found the deformability of cells from patients on an LVAD for 1-126 days to be reduced $[69,70]$. Complications include anemia with a high reticulocyte count suggesting a rapid turnover of cells [13], and circulatory lifespans as short as 30 days have been reported for an axial flow LVAD [13].

Reduced deformability of red blood cells has also been reported for prosthetic heartvalve patients. It has been attributed to supraphysiologic shear stress [71-74]. Degree of cell stiffness has been shown to vary inversely with the level of RBCs in the blood as indicated by the patient's hematocrit. Consistent with these observations, shorter circulatory lifespans of erythrocytes have been reported in patients with prosthetic heart valves $[73,74]$. While the normal lifespan of RBCs is about 120 days, the reported red cell lifespans with a mechanical heart valve is 99 days and 103 days with a bioprosthesis or xenograft [74]. Laboratory experiments of flow through a valve support the hypothesis that the level of mechanical trauma is sufficient to cause the abridged lifespan (see below). Selective removal of injured cells has been demonstrated by exposing red blood cells from New Zealand white rabbits to shear stress in oscillatory flow for $60 \mathrm{~min}$ at levels ranging from $0.5-12 \mathrm{~Pa}$ and then perfusing a mixture of labelled control and sheared cells through a spleen ex vivo in a flow loop [21]. Injured cells disappeared more rapidly than controls and the rate of removal for sheared cells increased with the magnitude of the shear stress applied. Computational fluid dynamics simulations also indicate that turbulent flow through prosthetic heart valves is sufficient to harm RBCs [25,75-77].

High flow rates through constrictions during hemodialysis also cause supraphysiological stresses that, in addition to metabolic factors, may account for reduced deformability of cells from this patient group. Results in the literature, however, are inconclusive, though 
it seems clear that cells from hemodialysis are rigid in comparison to red cells from healthy individuals [78-83]. This continues to be true after dialysis [82,83], but measurements pre- and post-hemodialysis are reported as worse [82], the same [79,81,84], or better [83]. Erythrocytes from patients on continuous ambulatory peritoneal dialysis (CAPD) without the exposure to stress have more flexible cells [78,82].

\subsection{In Vitro and In Vivo Studies of Mechanical Trauma to Erythrocytes}

Our understanding of sublethal stress and deformability has been advanced by simulated trauma applied to normal cells in the laboratory. In general, erythrocytes are isolated from whole blood by centrifugation, then washed and resuspended in phosphate-buffered saline before being exposed to shear stress in a viscometer. Other methods to apply mechanical trauma include forcing the cells through a narrow bore needle [64] and rocking of a test tube containing cells and a metal shot [31]. Cells from human volunteers are often used, but erythrocytes from other mammals have also been studied. As such, it is important to appreciate that species differences in red cells exist at least in terms of susceptibility to hemolysis [85]. All together, these studies have helped to establish conditions harmful to the cell that can be used in the design of medical devices with blood flow while also indicating that plasma offers some protection [31].

The in vivo link between mechanical trauma and accelerated removal from the circulation has been shown by several groups. Red cell survival time in dogs on long term perfusion (16-45 h) with a small diaphragm pump dropped from 25 days for controls to about 15 days [18]. Reinfusing labelled canine cells sheared at $90 \mathrm{~Pa}$, Nanjappa et al. found that circulatory half-life decreased with length of exposure time [86]. While deformability was not measured, subsequent in vitro experiments have firmly established a relationship between mechanical trauma and cell rigidity. In fact, altered rheology was one of the first properties appreciated for mechanically traumatized erythrocytes. Exposure to shear stresses of 35-140 Pa for 2 min resulted in reduced deformability as manifested in a higher pressure drop during flow through a Nuclepore filter $[33,34]$. Prior to measuring cell rigidity, Lee et al. pre-sheared human cells in the ektacytometer by varying shear stress from $0,56.4,84.6$ to $112.8 \mathrm{~Pa}$ for $30 \mathrm{~s}$ exposure and by varying exposure times from 0,30 , 120,180 to $3600 \mathrm{~s}$ for a stress of $56.8 \mathrm{~Pa}$ [87]. With the above threshold values, EI decreased steadily for both series. They concluded that the threshold for damage was approximately $30 \mathrm{~Pa}$ for a $2 \mathrm{~min}$ exposure. Simmonds et al. conducted similar studies for stresses of 1,4 , 16, 32 and $64 \mathrm{~Pa}$ with exposure times at 1, 4, 16, 32 and $64 \mathrm{~s}$ [32]. A statistically significant difference in the maximum value of the EI, EImax, was found for an exposure time of $32 \mathrm{~s}$ at $32 \mathrm{~Pa}$ and as short as $4 \mathrm{~s}$ at $64 \mathrm{~Pa}$. The results by Lee et al. are bounded with an observation of no loss of deformability after $1 \mathrm{~h}$ at $6 \mathrm{~Pa}$ by others [88]. Notably, low stresses appear to improve deformability under some conditions [37,89]. Meram et al. hypothesized that this improvement in RBC deformability by shear stress may reflect the accumulation of "products" which may be involved in the active regulation of RBC deformability [89].

Stresses on cells in a medical device tend to be high stresses of brief duration occurring multiple times. Thus, it is important that the effect of intermittent exposures on red cell flexibility has also been examined [37,90]. No change in deformability of porcine erythrocytes was observed after $8 \mathrm{~h}$ under $3 \mathrm{~Hz}$ oscillations with a peak stress of $211 \mathrm{~Pa}$ [91]. However, after an initial increase, McNamee et al. found a steady decline in EImax (or deformability) with a series of $3 \mathrm{~s}$ exposures at $64 \mathrm{~Pa}$ or $2 \mathrm{~s}$ exposures at $88 \mathrm{~Pa}$, for 10 repeated bouts [92]. Shear at $100 \mathrm{~Pa}$ of $1 \mathrm{~s}$ duration every $60 \mathrm{~s}$ resulted in a statistically significant decrease in EImax after only 15 cycles [10]. Employing a microfluidics system and cyclic electrodeformations of approximately $1 \mathrm{~s}$, Qiang observed a decrease in elongation over hundreds of cycles [54].

Horobin et al. [38] were the first to evaluate the relative tolerance of RBCs to specific shear about the subhemolytic threshold (SHT), which is about $80 \mathrm{~Pa}$. Interestingly, they found that while exposure to shear stress below SHT can increase RBC deformability, in agreement with an earlier report [36], shear stress above SHT impairs RBC deformability. 
Investigators of in vitro studies of mechanical trauma have tended to conduct experiments with washed erythrocytes. Kameneva et al. [31] compared RBC damage when RBCs were suspended in plasma and in PBS solutions. As a result, the $30 \%$ replacement of plasma with the PBS solution caused a statistically significant increase in the mechanically induced damage to RBCs. This occurs because plasma albumin has a very strong protective effect at concentrations similar to the physiological total plasma protein concentration.

\section{Erythrocyte Membrane after Sublethal Trauma}

The red blood cell membrane consists of an external lipid bilayer covering a proteinaceous cytoskeleton (see Figure 1). Considerable evidence indicates structural changes to the cell membrane after stress. Dao used fluorescence polarization with the probe 1,6-diphenylhexatriene to show increased rotational freedom and a decrease in anisotropy of the lipid bilayer in human erythrocytes after shear at $100 \mathrm{~Pa}$ for 2 min (Figure 7) [93]. The result suggests increased disorder. Structural changes also occur in membrane proteins such as band 3. Sublethal trauma caused an increase band 3 density on smaller, less deformable red cells from a goat [94]. Ohta et al. examined the red cell membrane of ovine red blood cells with atomic force microscopy (AFM) after trauma in a concentric cylinder viscometer at shear rates of $0,10,000$ and $50,000 s^{-1}$ for $10 s$ [95]. Roughness values of cell membranes increased with stress from $4.5 \pm 1.5,6.9 \pm 2.1$ and $10.1 \pm 2.4 \mathrm{~nm}$, respectively.
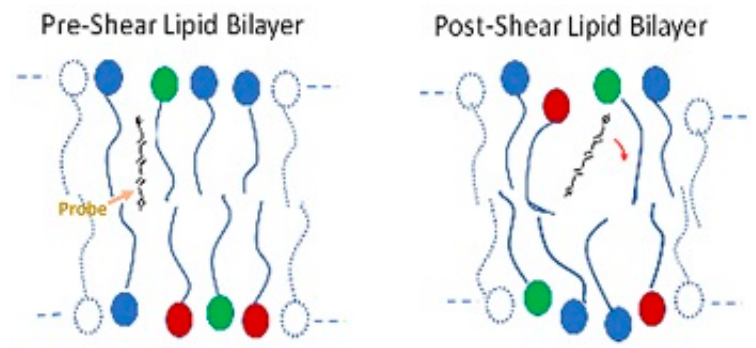

Figure 7. Illustration of the freedom of movement of a molecular probe and bilayer anisotropy.

Indeglia et al. examined lipids of canine RBCs after trauma at $1500 \mathrm{~Pa}$ and observed a decrease in the phospholipid to cholesterol ratio [96]. Lipids in the bilayer include phosphatidylethanolamine, phosphatidylserine and others. The composition of phospholipids in the inner and outer leaflets of the lipid bilayer is not the same. An enzyme flippase acts to move negatively charged phosphotidylserine (PS) molecules to the interior leaflet from the exterior leaflet, while floppase causes the migration of neutral phospholipid to the exterior. This is important because the presence of PS on the exterior surface is a signal for eryptosis, the red cell version of programmed cell death [97]. Increased disorder leading to PS expression could be an explanation for the shortened half-life observations of RBCs. However, exposing washed red cells from human donors to shear in a microfluidics channel at $100,000 \mathrm{~s}^{-1}$ for $0-15 \mathrm{~ms}$, Buerck et al. failed to detect increased PS presence with flow cytometry and tagged Annexin V [98].

A recent report suggests motion of the erythrocyte transmembrane protein band 3 functions as a biological clock to determine the physiological life span of the erythrocyte [99]. Conformational dynamics expose the senescent cell antigen on band 3 to which naturally occurring antibodies bind. The binding of IgG plays a role in the removal of the cell in the spleen through macrophage phagocytosis. It is believed that slower passage of stiffer cells facilitates this process. Buerck et al. [98] found that in vitro subhemolytic stress applied to human red cells induced binding of immunoglobulin to the membrane, providing a component complementary to deformability for the mechanism of shortened cell lifespan due to sublethal trauma.

Sutera was one of the first researchers to recognize that membrane fragments might be lost during subhemolytic trauma [22]. Microparticles appear in the blood of patients on LVADs, with those from red cells having the highest concentration [100]. Microparticle for- 
mation from platelets, leukocytes, and endothelial cells can be attributed to inflammatory species [101], while shear stress seems a more likely factor for erythrocyte microparticles (ErMPs). Laboratory experiments have confirmed the formation of ErMPs with shear stress [11]. Similar to other measures of cell injury, the number of erythrocyte microparticles depends on both exposure time and magnitude of the shear stress [11]. Watanabe et al. observed cell fragments of human cells in a cone-and-plate shear system after a $40 \mathrm{~s}$ exposure to a stress of $288 \mathrm{~Pa}$ [102]. Changes in morphology were also apparent with fragmentation. McNamee found biconcave discs, echinocytes, acanthocytes, and schistocytes on observation by light microscopy [92]. However, other researchers have reported conditions where morphology was unaffected. Even with shear at 15, 25, and $50 \mathrm{~Pa}$ for 3-4 h, Lubowitz found cells returned to their original shape afterwards [103]. Velker examined cells with SEM and found no change for higher stress levels and shorter exposure times [34].

\section{Ion Fluxes and Loss of Cell Volume}

Many groups have examined ion fluxes across the red cell membrane and their effects on the cell. Fluxes of ions are important because they influence the rheology and other properties of the red blood cell. Kirkpatrick et al. introduced calcium into a normal erythrocyte with the ionophore A23187 [104]. At $5 \mu \mathrm{M}$ concentration, the cell shrank, and its filterability increased, while higher calcium concentrations resulted in a marked decrease in filterability with a further reduction in size. Large potassium effluxes and much smaller sodium influxes accompanied these changes. Working with calcium concentrations similar to those in plasma, $\mathrm{O}^{\prime}$ Rear et al. linked increasing calcium influxes to the level of shear (0-130 Pa, $120 \mathrm{~s})$ with an inverse relationship to filterability through a $3 \mu \mathrm{m}$ pore size Nuclepore membrane [72]. Fluxes for sodium and potassium were similar to those found by Kirkpatrick et al., but changes in mean cell volume (MCV) were not significant. Working with cells in HEPES-Na, Oonishi exposed cells to stress by passage of a $40 \%$ hematocrit suspension through a $25 \mathrm{G}$ needle ( $30 \mathrm{~mm}$ long; $5 \mathrm{~mm}$ ID) and then measured filterability with a $4.4 \mu \mathrm{m}$ pore-size nickel mesh membrane [64]. Filterability decreased with the magnitude of the stress in $50 \mu \mathrm{M}$ extracellular calcium and with the level of calcium up to $50 \mu \mathrm{M}$ [64]. There was no change in morphology and no change in cell volume until $60 \mathrm{~min}$ after the stress was imposed. Pre-incubation with the calcium channel blockers nifedipine and felodipine prevented the impairment of cell rheology. Pentoxifylline, a potent phosphodiesterase inhibitor, was found to significantly improve the impaired deformability due to mechanical trauma.

\section{Aggregation}

Plasma proteins in human blood-like fibrinogen adsorb on the surface of the erythrocyte membrane. This facilitates the aggregation or stacking of red cells in structures called rouleaux. Rouleaux are responsible for the shear thinning character of blood as these aggregates break up with shear rate causing the viscosity to decrease. Ordinarily, bovine blood does not exhibit this phenomenon, yet aggregation for a calf on a circulatory assist device occurs [14]. This can be attributed to a decrease in the surface charge on the membrane which results from loss of sialic acid [105,106]. McNamee exposed fresh red cells from volunteers to three cycles of $125 \mathrm{~Pa}$ for $1.5 \mathrm{~s}$ and observed increased aggregability with a higher shear rate required to break up rouleaux compared to controls [41]. A reduction in sialic acid on the surface corresponded to a decrease in electrophoretic mobility. It is likely that the change in surface charge explains the greater adhesion of sheared red blood cells to endothelial cells in vitro.

\section{Ageing and Mechanical Trauma}

As mentioned already, the lifespan of a normal RBC is about 120 days. As cells age, there is increased binding of natural antibodies to the senescent cell antigen on the membrane protein band $3[107,108]$. The dynamics of this transmembrane protein were recently proposed as the biological clock leading to removal of RBCs [109]. Many investigators have 
noted the similarity of injured red blood cells to senescent cells $[13,98,106,110]$. The volume of cells is reduced and density increased, they are stiffer and they are removed from the circulation by the spleen. Correspondence between age and density is usually assumed in studying the properties of red blood cells with age as density gradient separation methods are used. Both low-density and high-density cells are injured by shear (64 Pa for $300 \mathrm{~s}$ ), but the effects of trauma are harsher on the older cells [111]. Similar to senescent cells, erythrocytes exposed to shear also show enhanced binding of immunoglobulin IgG [98].

\section{Summary}

Investigation of hemolysis, anemia, or thrombosis in CAD patients requires attention to the biochemical and rheological impact of sublethal damage to blood. As a result of supraphysiological shear stresses, mechanical properties of RBCs may be altered and RBC deformability affected. Exposure to short-term and repeated shear stress in circulation also leads to accumulated sublethal damage. Table 1 summarizes the RBC damage studies. Lysis of the cell membrane is always important, and there has been a lot of progress in developing hemolysis models under different flow conditions and different Reynolds number regimes. However, recent evidence suggests that cell damage without membrane rupture can have drastic effects on the lifetime of RBCs and on their functionality. Predictive models and criteria for subhemolytic damage should be developed based on accurate experimental measurements or based on high-fidelity computations.

Table 1. Summary of the references for RBC damage.

\begin{tabular}{|c|c|c|c|}
\hline $\begin{array}{l}\text { References for } \\
\text { RBC Damage }\end{array}$ & Cell Type & Test Method & $\begin{array}{l}\text { Critical Stress } \\
\text { Magnitude }\end{array}$ \\
\hline Horobin et al. [10] & Human blood & Ektacytometer & $100 \mathrm{~Pa}$ \\
\hline Buerck et al. [11] & Human blood & Microfluidic channel & $100,000 \mathrm{~s}^{-1}$ \\
\hline Sandza et al. [21] & Human blood & Tube flow apparatus & $30-50 \mathrm{~Pa}$ \\
\hline Aziz et al. [28] & Porcine blood & Stirred-Tank Model & $10 \mathrm{~Pa}$ \\
\hline Kameneva et al. [31] & Human and bovine blood & Centrifugation & - \\
\hline Simmonds et al. [32] & Human blood & Laser-diffraction ektacytometer & $64 \mathrm{~Pa}$ \\
\hline O'Rear et al. [33] & Human blood & Filtration method & $100-130 \mathrm{~Pa}$ \\
\hline Velker et al. [34] & Human blood & Nucleopore filters & $25-140 \mathrm{~Pa}$ \\
\hline Simmonds et al. [37] & Human blood & Couette type shearing system & $30-40 \mathrm{~Pa}$ \\
\hline Horobin et al. [38] & Human blood & Ektacytometry & 5-100 Pa \\
\hline Barabino et al. [39] & Human blood & Video microscopy and digital image processing & $25-500 s^{-1}$ \\
\hline McNamee et al. [40] & Human blood & Couette shearing system & $50 \mathrm{~Pa}, 100 \mathrm{~Pa}$ \\
\hline McNamee et al. [41] & Human blood & Poiseuille shearing system & $125 \mathrm{~Pa}$ \\
\hline Sakota et al. [42] & Fresh porcine blood & Rotary blood pumps & - \\
\hline Qiang et al. [54] & Human blood & Microfluidic chips & $150 \mathrm{~Pa}$ \\
\hline Renoux et al. [59] & Human blood & Osmotic gradient ektacytometry & $3 \mathrm{~Pa}$ \\
\hline Mohandas et al. [60] & Human blood & Ektacytometer & $7.5 \mathrm{~Pa}$ \\
\hline Reid et al. [64] & Human blood & Filtration & - \\
\hline Oonishi et al. [64] & Human blood & Nickel mesh filter & $660 \mathrm{~Pa}$ \\
\hline Ding et al. [85] & Human, ovine, porcine, and bovine blood & Two single-pass blood-shearing devices & $25-320 \mathrm{~Pa}$ \\
\hline Lee et al. [87] & Human blood & Ektacytometry & $30 \mathrm{~Pa}$ \\
\hline Hashimoto et al. [89] & Human blood & Centrifugal method & $0.6-6 \mathrm{~Pa}$ \\
\hline Meram et al. [89] & Human blood & Laser diffraction ektacytometer system & $5-20 \mathrm{~Pa}$ \\
\hline Watanabe et al. [90] & Porcine blood & Cyclically reversing shear flow generator & $211 \mathrm{~Pa}$ \\
\hline Watanabe et al. [91] & Human blood & Cyclically reversing shear flow generator & $128 \mathrm{~Pa}$ \\
\hline Dao et al. [93] & Human blood & Fluorescence anisotropy & $100 \mathrm{~Pa}$ \\
\hline Mizuno et al. [94] & Goat blood & Cobb and Beth [112] & $420 \mathrm{~s}^{-1}$ \\
\hline Ohta et al. [95] & Sheep erytrocytes & Atomic force microscope & 10,000 and $50,000 \mathrm{~s}^{-1}$ \\
\hline Watanabe et al. [102] & Human blood & Special shear flow chamber & $288 \mathrm{~Pa}$ \\
\hline Lubowitz et al. [103] & Human blood & Couette viscometer & $50 \mathrm{~Pa}$ \\
\hline Kirkpatrick et al. [104] & Human blood & Filtration & $1334 \mathrm{~Pa}$ \\
\hline Kameneva et al. [106] & Human and animal blood & Hemolyzer device & $0.0596 \mathrm{~s}^{-1}$ \\
\hline Buerck et al. [98] & Human blood & viscometer and microfluidics channels & $10-130 \mathrm{~Pa}$ \\
\hline McNamee et al. [111] & Human blood & osmotic gradient ektacytometry & $64 \mathrm{~Pa}$ \\
\hline
\end{tabular}

Funding: This research received no external funding.

Institutional Review Board Statement: Not applicable. 
Informed Consent Statement: Not applicable.

Acknowledgments: The authors appreciate the assistance of Paige Frey in the preparation of the manuscript.

Conflicts of Interest: The authors declare no conflict of interest.

\section{References}

1. Dupire, J.; Socol, M.; Viallat, A. Full dynamics of a red blood cell in shear flow. Proc. Natl. Acad. Sci. USA 2012, 109, 20808-20813. [CrossRef]

2. Li, X.; Peng, Z.; Lei, H.; Dao, M.; Karniadakis, G.E. Probing red blood cell mechanics, rheology and dynamics with a twocomponent multi-scale model. Philos. Trans. A Math. Phys. Eng. Sci. 2014, 372, 20130389. [CrossRef] [PubMed]

3. Noguchi, H.; Gompper, G. Shape transitions of fluid vesicles and red blood cells in capillary flows. Proc. Natl. Acad. Sci. USA 2005, 102, 14159-14164. [CrossRef] [PubMed]

4. Discher, D.E.; Carl, P. New insights into red cell network structure, elasticity, and spectrin unfolding-A current review. Cell. Mol. Biol. Lett. 2001, 6, 593-606.

5. Crow, S.; John, R.; Boyle, A.; Shumway, S.; Liao, K.; Colvin-Adams, M.; Toninato, C.; Missov, E.; Pritzker, M.; Martin, C.; et al. Gastrointestinal bleeding rates in recipients of nonpulsatile and pulsatile left ventricular assist devices. J. Thorac. Cardiovasc. Surg. 2009, 137, 208-215. [CrossRef]

6. Piccione, W. Left ventricular assist device implantation: Short and long-term surgical complications. J. Heart Lung Transplant. 2000, 19, S89-S94. [CrossRef]

7. Zhang, P.; Yeo, J.H.; Qian, P.; Hwang, N.H.C. Shear Stress Investigation Across Mechanical Heart Valve. ASAIO J. 2007, 53, 530-536. [CrossRef]

8. Skalak, R.; Chien, S.; Mates, R.E. Handbook of Bioengineering. J. Biomech. Eng. 1987, 109, 357. [CrossRef]

9. Leverett, L.B.; Hellums, J.D.; Alfrey, C.P.; Lynch, E.C. Red Blood Cell Damage by Shear Stress. Biophys. J. 1972, 12, 257-273. [CrossRef]

10. Horobin, J.; Sabapathy, S.; Simmonds, M. Repetitive Supra-Physiological Shear Stress Impairs Red Blood Cell Deformability and Induces Hemolysis. Artif. Organs 2017, 41, 1017-1025. [CrossRef]

11. Buerck, J.P.; Burke, D.K.; Schmidtke, D.W.; Snyder, T.A.; Papavassiliou, D.V.; O'Rear, E.A. Production of erythrocyte microparticles in a sub-hemolytic environment. J. Artif. Organs 2021, 24, 135-145. [CrossRef] [PubMed]

12. Mitlyng, B.L.; Chandrashekhar, Y.; Furne, J.K.; Levitt, M.D. Use of Breath Carbon Monoxide to Measure the Influence of Prosthetic Heart Valves on Erythrocyte Survival. Am. J. Cardiol. 2006, 97, 1374-1376. [CrossRef] [PubMed]

13. Taimeh, Z.; Koene, R.J.; Furne, J.; Singal, A.; Eckman, P.M.; Levitt, M.D.; Pritzker, M.R. Erythrocyte aging as a mechanism of anemia and a biomarker of device thrombosis in continuous-flow left ventricular assist devices. J. Heart Lung Transplant. 2017, 36, 625-632. [CrossRef] [PubMed]

14. Olia, S.; Maul, T.M.; Antaki, J.F.; Kameneva, M.V. Mechanical Blood Trauma in Assisted Circulation: Sublethal RBC Damage Preceding Hemolysis. Int. J. Artif. Organs 2016, 39, 150-159. [CrossRef] [PubMed]

15. Bernstein, E.F.; Castaneda, A.R.; Varco, R.L. Some Biologic Limitations to Prolonged Blood Pumping. ASAIO J. 1965, 11, 118-121. [CrossRef] [PubMed]

16. Brinsfield, D.E.; Hopf, M.A.; Geering, R.B.; Galletti, P.M. Hematological changes in long-term perfusion. J. Appl. Physiol. 1962, 17, 531-534. [CrossRef]

17. Galletti, P.M. Laboratory experience with 24 hour partial heart-lung bypass. J. Surg. Res. 1965, 5, 97-104. [CrossRef]

18. Kusserow, B.K.; Clapp, J.F. Red Blood Cell Survival After Prolonged Perfusion With A Blood Pump. ASAIO J. 1966, 12, $121-123$. Available online: https://journals.lww.com/asaiojournal/Fulltext/1966/04000/RED_BLOOD_CELL_SURVIVAL_AFTER_ PROLONGED_PERFUSION.27.aspx (accessed on 28 November 2021).

19. Bernstein, E.F.; Indeglia, R.A.; Shea, M.A.; Varco, R.L. Sublethal Damage to the Red Blood Cell from Pumping. Circulation 1967, 35, I226-I233. [CrossRef]

20. Bernstein, E.F.; Blackshear, P.L.; Keller, K.H. Factors influencing erythrocyte destruction in artificial organs. Am. J. Surg. 1967, 114, 126-138. [CrossRef]

21. Sandza, J.G.; Clark, R.E.; Weldon, C.S.; Sutera, S.P. Subhemolytic trauma of erythrocytes: Recognition and sequestration by the spleen as a function of shear. Trans. Am. Soc. Artif. Intern. Organs 1974, 20, 457-462. [PubMed]

22. Sutera, S.P. Flow-induced trauma to blood cells. Circ. Res. 1977, 41, 2-8. [CrossRef]

23. Faghih, M.M.; Sharp, M.K. Modeling and prediction of flow-induced hemolysis: A review. Biomech. Model. Mechanobiol. 2019, 18, 845-881. [CrossRef] [PubMed]

24. Kameneva, M.V.; Burgreen, G.W.; Kono, K.; Repko, B.; Antaki, J.F.; Umezu, M. Effects of Turbulent Stresses upon Mechanical Hemolysis: Experimental and Computational Analysis. ASAIO J. 2004, 50, 418-423. [CrossRef] [PubMed]

25. James, M.E.; Papavassiliou, D.V.; O’Rear, E.A. Use of Computational Fluid Dynamics to Analyze Blood Flow, Hemolysis and Sublethal Damage to Red Blood Cells in a Bileaflet Artificial Heart Valve. Fluids 2019, 4, 19. [CrossRef]

26. Ozturk, M.; Papavassiliou, D.V.; O’Rear, E.A. An Approach for Assessing Turbulent Flow Damage to Blood in Medical Devices. J. Biomech. Eng. 2017, 139, 011008. [CrossRef] 
27. Ozturk, M.; O’Rear, E.A.; Papavassiliou, D.V. Hemolysis Related to Turbulent Eddy Size Distributions Using Comparisons of Experiments to Computations. Artif. Organs 2015, 39, E227-E239. [CrossRef] [PubMed]

28. Aziz, A.; Werner, B.C.; Epting, K.L.; Agosti, C.D.; Curtis, W.R. The cumulative and sublethal effetcs of turbulence on erythrocytes in a stirred-tank model. Ann. Biomed. Eng. 2007, 35, 2108-2120. [CrossRef]

29. Koutsiaris, A.G.; Tachmitzi, S.V.; Batis, N. Wall shear stress quantification in the human conjunctival pre-capillary arterioles in vivo. Microvasc. Res. 2013, 85, 34-39. [CrossRef]

30. Deutsch, S.; Tarbell, J.M.; Manning, K.B.; Rosenberg, G.; Fontaine, A.A. Experimental Fluid Mechanics of Pulsatile Artificial Blood Pumps. Annu. Rev. Fluid Mech. 2006, 38, 65-86. [CrossRef]

31. Kameneva, M.V.; Antaki, J.F.; Yeleswarapu, K.K.; Watach, M.J.; Griffith, B.P.; Borovetz, H.S. Plasma protective effect on red blood cells exposed to mechanical stress. ASAIO J. 1997, 43, M571-M575. [CrossRef] [PubMed]

32. Simmonds, M.J.; Meiselman, H.J. Prediction of the level and duration of shear stress exposure that induces subhemolytic damage to erythrocytes. Biorheology 2017, 53, 237-249. [CrossRef] [PubMed]

33. O'Rear, E.A.; Udden, M.M.; McIntire, L.V.; Lynch, E.C. Reduced erythrocyte deformability associated with calcium accumulation. Biochim. Biophys. Acta (BBA) Biomembr. 1982, 691, 274-280. [CrossRef]

34. Velker, J.A.; Mclntire, L.V.; Lynch, E.C. Alteration of erythrocyte deformability due to shear stress as assessed by nuclepore filters ASAIO J. 1977, 23, 732-735. [CrossRef] [PubMed]

35. Chen, Z.; Sun, A.; Wang, H.; Fan, Y.; Deng, X. Non-physiological shear stress-induced blood damage in ventricular assist device Med. Nov. Technol. Devices 2019, 3, 100024. [CrossRef]

36. Fraser, K.H.; Zhang, T.; Taskin, M.E.; Griffith, B.P.; Wu, Z.J. A quantitative comparison of mechanical blood damage parameters in Rotary Ventricular Assist Devices: Shear stress, exposure time, and hemolysis index. J. Biomech. Eng. 2012, 134, 81002. [CrossRef] [PubMed]

37. Simmonds, M.J.; Atac, N.; Baskurt, O.K.; Meiselman, H.J.; Yalcin, O. Erythrocyte deformability responses to intermittent and continuous subhemolytic shear stress. Biorheology 2014, 51, 171-185. [CrossRef]

38. Horobin, J.; Sabapathy, S.; Simmonds, M.J. Red blood cell tolerance to shear stress above and below the subhemolytic threshold. Biomech. Model. Mechanobiol. 2020, 19, 851-860. [CrossRef] [PubMed]

39. Barabino, G.A.; McIntire, L.V.; Eskin, S.G.; Sears, D.A.; Udden, M. Endothelial cell interactions with sickle cell, sickle trait, mechanically injured, and normal erythrocytes under controlled flow. Blood 1987, 70, 152-157. [CrossRef]

40. McNamee, A.P.; Tansley, G.D.; Simmonds, M.J. Sublethal mechanical shear stress increases the elastic shear modulus of red blood cells but does not change capillary transit velocity. Microcirculation 2020, 27, e12652. [CrossRef]

41. McNamee, A.P.; Tansley, G.D.; Simmonds, M.J. Sublethal mechanical trauma alters the electrochemical properties and increases aggregation of erythrocytes. Microvasc. Res. 2018, 120, 1-7. [CrossRef] [PubMed]

42. Sakota, D.; Sakamoto, R.; Sobajima, H.; Yokoyama, N.; Waguri, S.; Ohuchi, K.; Takatani, S. Mechanical Damage of Red Blood Cells by Rotary Blood Pumps: Selective Destruction of Aged Red Blood Cells and Subhemolytic Trauma. Artif. Organs 2008, 32, 785-791. [CrossRef]

43. Khoo, D.P.; Cookson, A.N.; Gill, H.S.; Fraser, K.H. Normal fluid stresses are prevalent in rotary ventricular assist devices: A computational fluid dynamics analysis. Int. J. Artif. Organs 2018, 41, 738-751. [CrossRef]

44. Fischer, T.; Schmid-Schönbein, H. Tank Tread Motion of Red Cell Membranes in Viscometric Flow: Behavior of Intracellular and Extracellular Markers (with Film). Blood Cells 1977, 3, 351-365.

45. Faghih, M.M.; Sharp, M.K. Deformation of human red blood cells in extensional flow through a hyperbolic contraction. Biomech Model. Mechanobiol. 2020, 19, 251-261. [CrossRef] [PubMed]

46. Lee, S.S.; Yim, Y.; Ahn, K.H.; Lee, S.J. Extensional flow-based assessment of red blood cell deformability using hyperbolic converging microchannel. Biomed. Microdevices 2009, 11, 1021-1027. [CrossRef]

47. Foster, K.M.; Papavassiliou, D.V.; O’Rear, E.A. Elongational Stresses and Cells. Cells 2021, 10, 2352. [CrossRef]

48. Purvis, N.; Giorgio, T. The effects of elongational stress exposure on the activation and aggregation of blood platelets. Biorheology 1991, 28, 355-367. [CrossRef]

49. Suwannaphan, T.; Srituravanich, W.; Sailasuta, A.; Piyaviriyakul, P.; Bhanpattanakul, S.; Jeamsaksiri, W.; Sripumkhai, W.; Pimpin, A. Investigation of Leukocyte Viability and Damage in Spiral Microchannel and Contraction-Expansion Array. Micromachines 2019, 10, 772. [CrossRef]

50. Kania, S.; Webb, E.B.; Oztekin, A.; Cheng, X.; Zhang, X. Rare Event Prediction of Von Willebrand Factor Multimer Unfolding in Extensional Flow. Biophys. J. 2021, 120, 297a. [CrossRef]

51. Zhussupbekov, M.; Rojano, R.M.; Wu, W.-T.; Massoudi, M.; Antaki, J.F. A Continuum Model for the Unfolding of von Willebrand Factor. Ann. Biomed. Eng. 2021, 49, 2646-2658. [CrossRef]

52. Bae, Y.B.; Jang, H.K.; Shin, T.H.; Phukan, G.; Tran, T.T.; Lee, G.; Hwang, W.R.; Kim, J.M. Microfluidic assessment of mechanical cell damage by extensional stress. Lab Chip 2016, 16, 96-103. [CrossRef] [PubMed]

53. Ning, L.; Chen, X.; Ning, L. A brief review of extrusion-based tissue scaffold bio-printing. Biotechnol. J. 2017, 12, 1600671. [CrossRef] [PubMed]

54. Qiang, Y.; Liu, J.; Dao, M.; Suresh, S.; Du, E. Mechanical fatigue of human red blood cells. Proc. Natl. Acad. Sci. USA 2019, 116, 19828-19834. [CrossRef] [PubMed] 
55. Musumeci, L.; Jacques, N.; Hego, A.; Nchimi, A.; Lancellotti, P.; Oury, C. Prosthetic Aortic Valves: Challenges and Solutions. Front. Cardiovasc. Med. 2018, 5, 46. [CrossRef]

56. Mebius, R.E.; Kraal, G. Structure and function of the spleen. Nat. Rev. Immunol. 2005, 5, 606-616. [CrossRef]

57. Buffet, P.A.; Milon, G.; Brousse, V.; Correas, J.-M.; Dousset, B.; Couvelard, A.; Kianmanesh, R.; Farges, O.; Sauvanet, A.; Paye, F.; et al. Ex Vivo perfusion of human spleens maintains clearing and processing functions. Blood 2006, 107, 3745-3752. [CrossRef]

58. Kim, J.; Lee, H.; Shin, S. Advances in the measurement of red blood cell deformability: A brief review. J. Cell. Biotechnol. 2015, 1, 63-79. [CrossRef]

59. Renoux, C.; Faivre, M.; Bessaa, A.; Da Costa, L.; Joly, P.; Gauthier, A.; Connes, P. Impact of surface-area-to-volume ratio, internal viscosity and membrane viscoelasticity on red blood cell deformability measured in isotonic condition. Sci. Rep. 2019, 9, 6771. [CrossRef]

60. Mohandas, N.; Clark, M.R.; Jacobs, M.S.; Shohet, S.B. Analysis of factors regulating erythrocyte deformability. J. Clin. Investig. 1980, 66, 563-573. [CrossRef]

61. Reid, H.L.; Barnes, A.J.; Lock, P.J.; Dormandy, J.A.; Dormandy, T.L. A simple method for measuring erythrocyte deformability. J. Clin. Pathol. 1976, 29, 855-858. [CrossRef]

62. Parrow, N.L.; Violet, P.-C.; Tu, H.; Nichols, J.; Pittman, C.A.; Fitzhugh, C.; Fleming, R.E.; Mohandas, N.; Tisdale, J.F.; Levine, M. Measuring Deformability and Red Cell Heterogeneity in Blood by Ektacytometry. J. Vis. Exp. 2018, 131, e56910. [CrossRef] [PubMed]

63. Nicolau, C.T.; Teitel, P.; Fotino, M. Loss of Plasticity of Erythrocytes coated with Incomplete Antibodies. Nature 1959, 184, 1808-1809. [CrossRef] [PubMed]

64. Oonishi, T.; Sakashita, K.; Uyesaka, N. Regulation of red blood cell filterability by $\mathrm{Ca}^{2+}$ influx and cAMP-mediated signaling pathways. Am. J. Physiol. Content 1997, 273, C1828-C1834. [CrossRef] [PubMed]

65. Gregersen, M.I.; Bryant, C.A.; Hammerle, W.E.; Usami, S.; Chien, S. Flow Characteristics of Human Erythrocytes through Polycarbonate Sieves. Science 1967, 157, 825-827. [CrossRef]

66. Guo, Q.; Duffy, S.P.; Matthews, K.; Santoso, A.T.; Scott, M.D.; Ma, H. Microfluidic analysis of red blood cell deformability. J. Biomech. 2014, 47, 1767-1776. [CrossRef]

67. Gossett, D.R.; Tse, H.T.K.; Lee, S.A.; Ying, Y.; Lindgren, A.G.; Yang, O.O.; Rao, J.; Clark, A.T.; Di Carlo, D. Hydrodynamic stretching of single cells for large population mechanical phenotyping. Proc. Natl. Acad. Sci. USA 2012, 109, 7630-7635. [CrossRef]

68. Han, J.J.; Acker, M.A.; Atluri, P. Left Ventricular Assist Devices Synergistic Model Between Technology and Medicine. Circulation 2018, 138, 2841-2851. [CrossRef]

69. Hung, T.C.; Butter, D.B.; Yie, C.L.; Kormos, R.L.; Borovetz, H.S.; Griffith, B.P.; Hardesty, R.L. Effects of long-term Novacor artificial heart support on blood rheology. ASAIO Trans. 1991, 37, M312-M313.

70. Hung, T.-C.; Butter, D.B.; Kormos, R.L.; Sun, Z.; Borovetz, H.S.; Griffith, B.P.; Yie, C.-L. Characteristics of Blood Rheology in Patients During Novacor Left Ventricular Assist System Support. ASAIO Trans. 1989, 35, 611-613. [CrossRef]

71. Chen, Y.; Belboul, A.; Berglin, E.; Roberts, D. A mathematical analysis of hemorheological changes during heart valve replacement J. Cardiovasc. Surg. 2000, 41, 37-43.

72. O'Rear, E.A.; Udden, M.M.; Farmer, J.A.; McIntire, L.V.; Lynch, E.C. Increased intracellular calcium and decreased deformability of erythrocytes from prosthetic heart valve patients. Clin. Hemorheol. Microcirc. 1984, 4, 461-471. [CrossRef]

73. Hirayama, T.; Roberts, D.; William-Olsson, G. Mechanical Trauma to Red Blood Cells Caused by Björk-Shiley and CarpentierEdwards Heart Valves. Scand. J. Thorac. Cardiovasc. Surg. 1985, 19, 253-256. [CrossRef] [PubMed]

74. Shapira, Y.; Vaturi, M.; Sagie, A. Hemolysis Associated with Prosthetic Heart Valves. Cardiol. Rev. 2009, 17, 121-124. [CrossRef] [PubMed]

75. de Tullio, M.; Nam, J.; Pascazio, G.; Balaras, E.; Verzicco, R. Computational prediction of mechanical hemolysis in aortic valved prostheses. Eur. J. Mech. B Fluids 2012, 35, 47-53. [CrossRef]

76. De Vita, F.; de Tullio, M.D.; Verzicco, R. Numerical simulation of the non-Newtonian blood flow through a mechanical aortic valve. Theor. Comput. Fluid Dyn. 2016, 30, 129-138. [CrossRef]

77. Zakaria, M.S.; Ismail, F.; Tamagawa, M.; Aziz, A.F.A.; Wiriadidjaja, S.; Basri, A.A.; Ahmad, K.A. Review of numerical methods for simulation of mechanical heart valves and the potential for blood clotting. Med. Biol. Eng. Comput. 2017, 55, 1519-1548. [CrossRef]

78. Udden, M.M.; O'Rear, E.A.; Kegel, H.; McIntire, L.V.; Lynch, E.C. Decreased deform ability of erythrocytes and increased intracellular calcium in patients with chronic renal failure. Clin. Hemorheol. Microcirc. 1984, 4, 473-481. [CrossRef]

79. Inauen, W.; Stäubli, M.; Descoeudres, C.; Galeazzi, R.L.; Straub, P.W. Erythrocyte deformability in dialysed and non-dialysed uraemic patients. Eur. J. Clin. Investig. 1982, 12, 173-176. [CrossRef] [PubMed]

80. Forman, S.; Bischel, M.; Hochstein, P. Erythrocyte Deformability in Uremic Hemodialyzed Patients. Ann. Intern. Med. 1973, 79, 841-843. [CrossRef] [PubMed]

81. Szikszai, Z.; Ujhelyi, L.; Imre, S.G. Effect of hemodialysis on the deformability and lipid peroxidation of erythrocytes in chronic renal failure. Clin. Hemorheol. Microcirc. 2003, 28, 201-207. [PubMed]

82. Sotirakopoulos, N.; Tsitsios, T.; Stambolidou, M.; Athanasiou, G.; Peiou, M.; Kokkinou, V.; Mavromatidis, K. The Red Blood Cell Deformability in Patients Suffering from End Stage Renal Failure on Hemodialysis or Continuous Ambulatory Peritoneal Dialysis. Ren. Fail. 2004, 26, 179-183. [CrossRef] [PubMed] 
83. Ibrahim, F.F.; Ghannam, M.M.; Ali, F.M. Effect of dialysis on erythrocyte membrane of chronically hemodialyzed patients. Ren. Fail. 2002, 24, 779-790. [CrossRef] [PubMed]

84. Bareford, D.; Lucas, G.; Stone, P.; Caldwell, N.; McGonigle, R.; Stuart, J. Erythrocyte deformability in chronic renal failure. Clin. Hemorheol. Microcirc. 2016, 6, 501-510. [CrossRef]

85. Ding, J.; Niu, S.; Chen, Z.; Zhang, T.; Griffith, B.P.; Wu, Z.J. Shear-Induced Hemolysis: Species Differences. Artif. Organs 2015, 39, 795-802. [CrossRef] [PubMed]

86. Nanjappa, B.N.; Chang, H.-K.; Glomski, C.A. Trauma of the Erythrocyte Membrane Associated with Low Shear Stress. Biophys. J. 1973, 13, 1212-1222. [CrossRef]

87. Lee, S.S.; Anh, K.H.; Lee, S.J.; Sun, K.; Goedhart, P.T.; Hardeman, M.R. Shear induced damage of red blood cells monitored by the decrease of their deformability. Korean Soc. Rheol. 2004, 16, 141-146.

88. Hashimoto, S.; Mochizuki, S.; Morita, Y. Effect of Aging on Deformability of Erythrocytes in Shear Flow. J. Syst. Cybern. Inform. 2005, 3, 90-93.

89. Meram, E.; Yilmaz, B.D.; Bas, C.; Atac, N.; Yalcin, O.; Meiselman, H.J.; Baskurt, O.K. Shear stress-induced improvement of red blood cell deformability. Biorheology 2013, 50, 165-176. [CrossRef]

90. Watanabe, N.; Sakota, D.; Ohuchi, K.; Takatani, S. Deformability of Red Blood Cells and Its Relation to Blood Trauma in Rotary Blood Pumps. Artif. Organs 2007, 31, 352-358. [CrossRef]

91. Watanabe, N.; Arakawa, Y.; Sou, A.; Kataoka, H.; Ohuchi, K.; Fujimoto, T.; Takatani, S. Deformability of human red blood cells exposed to a uniform shear stress as measured by a cyclically reversing shear flow generator. Physiol. Meas. 2007, 28, 531-545. [CrossRef]

92. McNamee, A.P.; Tansley, G.D.; Sabapathy, S.; Simmonds, M.J. Biphasic impairment of erythrocyte deformability in response to repeated, short duration exposures of supraphysiological, subhaemolytic shear stress. Biorheology 2016, 53, 137-149. [CrossRef]

93. Dao, K.; O’Rear, E.; Johnson, A.; Peitersen, S. Sensitivity of the erythrocyte membrane bilayer to subhemolytic mechanical trauma as detected by fluorescence anisotropy. Biorheology 1994, 31, 69-76. [CrossRef]

94. Mizuno, T.; Tsukiya, T.; Taenaka, Y.; Tatsumi, E.; Nishinaka, T.; Ohnishi, H.; Oshikawa, M.; Sato, K.; Shioya, K.; Takewa, Y.; et al. Ultrastructural Alterations in Red Blood Cell Membranes Exposed to Shear Stress. ASAIO J. 2002, 48, 668-670. [CrossRef]

95. Ohta, Y.; Otsuka, C.; Okamoto, H. Changes in surface roughness of erythrocytes due to shear stress: Atomic force microscopic visualization of the surface microstructure. J. Artif. Organs 2003, 6, 101-105. [CrossRef]

96. Indeglia, R.A.; Shea, M.A.; Forstrom, R.; Bernstein, E.F. Influence of mechanical factors on erythrocyte sublethal damage. Trans. Am. Soc. Artif. Intern. Organs 1968, 14, 264-272. [PubMed]

97. Qadri, S.M.; Bissinger, R.; Solh, Z.; Oldenborg, P.-A. Eryptosis in health and disease: A paradigm shift towards understanding the (patho)physiological implications of programmed cell death of erythrocytes. Blood Rev. 2017, 31, 349-361. [CrossRef]

98. Buerck, J.P.; Burke, D.K.; Schmidtke, D.; Snyder, T.; Papavassiliou, D.; O’Rear, E.A. A Flow Induced Autoimmune Response and Accelerated Senescence of Red Blood Cells in Cardiovascular Devices. Sci. Rep. 2019, 9, 19443. [CrossRef] [PubMed]

99. Badior, K.E.; Casey, J.R. Large conformational dynamics in Band 3 protein: Significance for erythrocyte senescence signalling. Biochim. Biophys. Acta (BBA) Biomembr. 2021, 1863, 183678. [CrossRef] [PubMed]

100. Sansone, R.; Stanske, B.; Keymel, S.; Schuler, D.; Horn, P.; Saeed, D.; Boeken, U.; Westenfeld, R.; Lichtenberg, A.; Kelm, M.; et al Macrovascular and microvascular function after implantation of left ventricular assist devices in end-stage heart failure: Role of microparticles. J. Heart Lung Transplant. 2015, 34, 921-932. [CrossRef]

101. Jeske, W.P.; Walenga, J.M.; Menapace, B.; Schwartz, J.; Bakhos, M. Blood cell microparticles as biomarkers of hemostatic abnormalities in patients with implanted cardiac assist devices. Biomark. Med. 2016, 10, 1095-1104. [CrossRef] [PubMed]

102. Watanabe, N.; Shimada, T.; Hakozaki, M.; Hara, R. Visualization of erythrocyte deformation induced by supraphysiological shear stress. Int. J. Artif. Organs 2018, 41, 838-844. [CrossRef]

103. Lubowitz, H.; Harris, F.; Mehrjardi, M.H.; Sutera, S.P. Shear-induced changes in permeability of human RBC to sodium. Trans. Am. Soc. Artif. Organs 1974, 20, 470-473.

104. Kirkpatrick, F.H.; Hillman, D.G.; La Celle, P.L. A23187 and red cells: Changes in deformability, $\mathrm{K}^{+}, \mathrm{Mg}^{2+}, \mathrm{Ca}^{2+}$ and $\mathrm{ATP}$. Experientia 1975, 31, 653-654. [CrossRef] [PubMed]

105. McNamee, A.P.; Fitzpatrick, T.; Tansley, G.D.; Simmonds, M.J. Sublethal Supraphysiological Shear Stress Alters Erythrocyte Dynamics in Subsequent Low-Shear Flows. Biophys. J. 2020, 119, 2179-2189. [CrossRef] [PubMed]

106. Kameneva, M.V.; Antaki, J.F.; Borovetz, H.S.; Griffith, B.P.; Butler, K.C.; Yeleswarapu, K.K.; Watach, M.J.; Kormos, R.L. Mechanisms of red blood cell trauma in assisted circulation. Rheologic similarities of red blood cell transformations due to natural aging and mechanical stress. ASAIO J. 1995, 41, M457-M460. [CrossRef]

107. Kay, M. Immunoregulation of Cellular Life Span. Ann. N. Y. Acad. Sci. 2005, 1057, 85-111. [CrossRef]

108. Franco, R.S.; Puchulu-Campanella, E.; Barber, L.A.; Palascak, M.B.; Joiner, C.H.; Low, P.; Cohen, R.M. Changes in the properties of normal human red blood cells during in vivo aging. Am. J. Hematol. 2013, 88, 44-51. [CrossRef]

109. Badior, K.E.; Casey, J.R. Molecular mechanism for the red blood cell senescence clock. IUBMB Life 2018, 70, 32-40. [CrossRef]

110. Maruyama, T.; Fukata, M.; Fujino, T. Physiological and pathophysiological significance of erythrocyte senescence, density and deformability: Important but unnoticed trinity. J. Biorheol. 2020, 34, 61-70. [CrossRef] 
111. McNamee, A.P.; Richardson, K.; Horobin, J.; Kuck, L.; Simmonds, M.J. Susceptibility of density-fractionated erythrocytes to subhaemolytic mechanical shear stress. Int. J. Artif. Organs 2019, 42, 151-157. [CrossRef] [PubMed]

112. Cobb, C.E.; Beth, A.H. Identification of the eosinyl-5-maleimide reaction site on the human erythrocyte anion-exchange protein: Overlap with the reaction sites of other chemical probes. Biochemistry 1990, 29, 8283-8290. [CrossRef] [PubMed] 